\title{
Mortgage Origination: Important Lessons for South Africa
}

\author{
Anthea P Amadi-Echendu \\ University of South Africa, Pretoria \\ amadiap@unisa.ac.za
}

Doi:10.5901/mjss.2014.v5n10p45

\section{Abstract}

Traditionally banks sold their own products and services. Mortgage origination (MO) only came to SA at the turn of the century. Although the initial consumer buy-in was small, the growth was phenomenal. By 2007 approximately $60 \%$ of all home loan applications in South Africa (SA) were sourced through origination. The entry of MO's to the market has drastically changed the banks' interactions and relations with home loan clients. MO's are seen as providing a meaningful service to buyers and best of all: this service is free to home loan applicants. This study provides a comparative study of mortgage origination in Australia, Canada, Singapore, New Zealand, The Netherlands and South Africa. It further examines the role of mortgage originators in South Africa. The study reveals that South Africa might have much to learn from other countries in terms of MO practices, and regulation within the MO industry. A mixed methods approach was followed in this study and the information was triangulated with literature studies.

Keywords: Mortgage originators, conveyancing, advisors, property, home loan and application

\section{Introduction}

Traditionally banks sold their own products and services. Mortgage Originators (MO's) source the majority of the home loan business in the UK, USA (called mortgage agents) and Australia (called brokers). Origination only came to SA at the turn of the century. Although the initial consumer buy-in was small, the growth was phenomenal. By 2007 approximately $60 \%$ of all home loan applications in South Africa (SA) were sourced through origination. MO seem to increase competition and lower costs (Ambrose \& Conklin, 2012).

\section{The Role of a Mortgage Originator in South Africa}

Mortgage Originators act as financial intermediaries matching borrowers with lenders in some circumstances, but predominantly assisting buyers in obtaining a loan from a financial institution and completing the home loan application process. The originator's primary role is to use its negotiating power and skills to obtain the best possible transaction from financial institutions for the home loan client. The entry of MO's to the market has drastically changed the banks' interactions and relations with home loan clients. Clients have more leverage and can exercise choice as to where to place their home loan account (Muchanya, 2014). The clients' direct interaction with the bank has declined in recent years while mortgage origination interaction has increased.

The need for standards and some form of regulation has led to the establishment of the National Association of Mortgage Originators (NAMO). NAMO is a voluntary, non-profit association (Property news, 2009). There have been calls for the government to regulate the local bond origination market. The MO's involvement in home loan processes are illustrated in Table 1 below.

Table 1: Mortgage Origination process

\begin{tabular}{|c|l|}
\hline Steps & \multicolumn{1}{c|}{ Procedure followed } \\
\hline 1 & MO may already make contact with client to conduct a pre-assessment (not in all cases) \\
\hline 2 & Customer signs an agreement to purchase a home with an estate agent \\
\hline 3 & Estate agent enquires how property will be financed \\
\hline 4 & Estate agent obtains the necessary information and forwards to MO \\
\hline 5 & MO contacts client and advises of different options available at different banks \\
\hline 6 & Purchaser chooses an option \\
\hline
\end{tabular}




\begin{tabular}{|c|l|}
\hline 7 & MO completes the documentation and submits it to the bank of choice \\
\hline 8 & MO communicates the progress of transaction to client \\
\hline 9 & MO confirms acceptance of the home loan with the bank \\
\hline 10 & MO explains the legal requirements to client \\
\hline
\end{tabular}

Source: Residential Property Report (2004)

Originators earn bigger commissions than those paid to estate agents in the past. MO's are seen as providing a meaningful service to buyers and best of all: this service is free to home loan applicants. The banks pay the MO and this cost is not passed on to the client. They also provide buyers with options. The loans of existing home loan holders can be 'switched', i.e. moved from the bank where the loan is held to another bank which provides better competitive rates, etc. As a result buyers do not have to remain with their current home loan provider. MO's target and assist clients who have owned their properties for 4-5 years, as their property values would have increased. These property value increases enable property owners to leverage their growing property wealth in order to use it for business ventures, educational needs, investing in new property, to name but a few options. This has forced banks to compete for business and improve their value proposition to clients.

\section{The Mortgage Originator Value Proposition in South Africa}

Before MO's came into the market, each buyer had to apply to their bank in person for their home loan. MO's are able to assist you from your premises, even after hours. MO's have contracts with all four major banks in SA and other non-bank lenders. They are able to apply to more than one bank. The buyer can then choose the deal that offers the best rates and terms (Property24, 2012). MO's are only rewarded financially when the home loan has been accepted by buyers and the bond has been registered in the Deeds Office. It is therefore in their interest to ensure that as many applications as possible are approved and that such approved applications register as quickly as possible. Furthermore, MO's normally have a banking background have a firm knowledge of how banks determine risk profiles, as well as the on-going changes banks make to their lending criteria and processes, etc. The MO's services are free to the buyer as they are paid by the banks. Banks have encouraged MO's to submit applications digitally which has enabled the client to enjoy the benefit in speed and efficiency.

\section{The Role of a Mortgage Originator in the Netherlands}

A mortgage originator also fulfils an insurance and financial advisory role in The Netherlands and is called a mortgage or financial advisor. One needs a special license to be a financial advisor for individuals. This is regulated by law for rentals and the purchase of property. The value proposition to clients is to show the best options available from different banks for the different loan terms. About 6 - 7 years ago, the mortgage advisors submitted more than one application for the same client and property to different banks, the so-called multi-submission. The banks now have a code of conduct for mortgage advisors which is regulated by government. Previously purchasers of property could secure full loans from banks without an own contribution. A ruling made by law now states that the loan to value must not exceed $100 \%$. The loan to value percentage lowers by $1 \%$ every year until only $90 \%$ loan to value loans will be offered by 2018 . Until December 2012 the mortgage advisor received commission from the bank where the loan was placed. It is now forbidden as the government stopped such payments. Instead the hours that the mortgage advisor worked on a transaction are calculated, and a fixed fee is charged. The advisor drafts a separate agreement with the buyer for this purpose (Kuling, 2013).

Duties of the mortgage advisor include submitting the finance application to a bank, underwriting life insurance, fire insurance, car insurance and household content insurance. A buyer should visit the mortgage advisor before purchasing a property in order to identify the documents needed for the transaction, work out the monthly payments, build an understanding of the property process and establish if he/she can afford the repayments of the purchase price. The mortgagee advisor uses a special programme called Mortgage Data Network (HDN). The system is owned by the banks, financial advisor companies and mortgage brokers. There are three companies in Holland that does mortgage administration for banks. The financial Advisor System is regulated and helps to manage milestones. The system is linked to the bank, but is not yet linked to the notary that will attend to the registration of the property title (Kuling, 2013).

The mortgage advisor has contact with the Deeds Registry, to receive updates regarding property transactions. The Financial Advisor has a license from the AFM (Authorities Financial Markets) and must be insured. He/she needs a 
diploma which takes 3-4 years to obtain. One has the option of becoming an insurance advisor without selling financial products, or one can become an insurance advisor and also sell financial products. There will be yearly exams at the AFM from 2014. Losses are monitored by the AFM (Kuling, 2013).

\section{Mortgage Origination in Canada and Singapore}

The laws governing mortgage brokerage in Canada are determined by provincial governments (Merix, n.d.). Most provinces require mortgage brokerage companies to carry a provincial license. The mortgage brokerage industry in Singapore is still new compared to the situation in the US and the UK. Not all the banks in Singapore are linked to mortgage brokerage firms. The mortgage brokers are mostly regulated by the Singapore Law of Agency (Jones, 2010).

\section{Mortgage origination in Australia}

Mortgage brokers have been active in Australia since the early 1980s, however they only became a dominant force in the mortgage industry during the late 1990s on the back of aggressive marketing by Aussie Home Loans and Wizard Home Loans (Tomlinson \& Burke, 2012). Approximately $35 \%$ of all loans secured by a mortgage in Australia were introduced by mortgage brokers in 2008. In March 2012, MFAA sources advised that the share of loans introduced by Mortgage Brokers had risen to $43 \%$. Traditionally the MO acts as an independent provider, not as a direct agent of the buyer or lender. The MO charges a direct fee to the borrower and earns an indirect fee from the lender (Berndt, Hollifield \& Sandas, 2010). The MO's services include completing the loan application form, performing financial and credit evaluations, providing loan option information to borrowers, as well as providing underwriting information to the lender (Berndt et al., 2010). An analysis of the current lending industry in Australia revealed that two out of five residential mortgage borrowers, or about 40 percent, now use brokers for their lending needs. During the 2012 calendar year, mortgage brokers wrote $\$ 100$ billion in mortgage loans, with an average home value for loans resting around $\$ 337,000$ (Orchard, 2013).

Mortgage brokers are now regulated by the Australian Securities and Investments Commission. The new national consumer credit protection legislation includes a licensing regime and responsible lending obligations. Mortgage brokers are also required to be a member of an external dispute resolution provider such as the Credit ombudsman service Limited (COSL). Furthermore, some lenders require accredited brokers to be a member of an industry body such as the Mortgage \& Finance Association of Australia (MFAA) (Orchard, 2013).

\section{Research Methodology}

A mixed methods approach was followed in this study and the information was triangulated with literature studies. A literature review was conducted to understand the role and application of mortgage originators in other countries and South Africa. A questionnaire was developed to look at buyer and seller behaviour in SA as well as show interactions that MO's have with other role-players in the property industry in SA. The questionnaires were circulated among the bigger originator companies, as well as a few smaller originators in SA. There are currently two bigger originators, namely Ooba and PA Betterbond. The information collected by means of a questionnaire was analysed using the SPSS Analytical tool and the results are discussed later on. Interviews were also conducted with the oldest mortgage originator in South Africa, as well as the Estate Agency Board and the Services Seta in SA. The interviews were analysed using content analysis.

\section{Findings and Implications}

The literature highlights the issue that originators in other countries are regulated by professional bodies. This body regulates their roles and responsibilities as well as compensation that they receive. Misconduct is appropriately handled by the bodies which enable mortgage origination to be promoted via professional institutions which maintain high standards of service and conduct. Certification is granted only by means of accredited training that needed to have taken place. This is not the case in SA as originators are only managed by means of service level agreements that have been signed with several of the bigger banks in SA. Perhaps SA can learn from the other countries in this regard. The role of a mortgage originator differs substantially from estate agencies. As a result, the Estate Agency Affairs Board would not be able to provide leadership in this regard. It would be more apt for mortgage Financial Services Board to incorporate the origination into their current structure, especially considering that originators assist buyers and existing homeowners to 
obtain loans for their properties. Results as analysed from the questionnaires are discussed below.

Table 1: Reconsideration after approval, but before attorney instruction

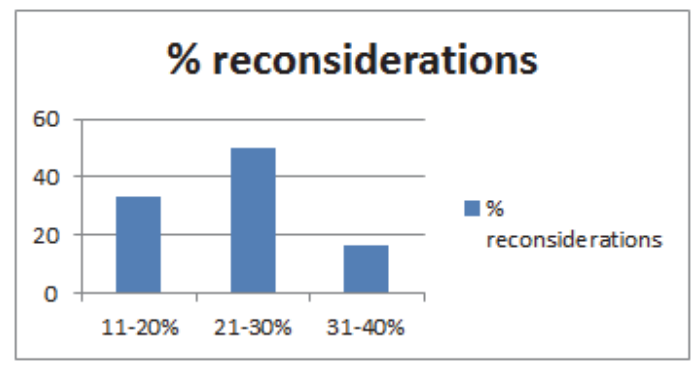

The table above illustrates that $11-40 \%$ of the applications received by MO's are resubmitted to financial institutions for reconsideration. The most popular reasons for reconsiderations are interest rate, loan amount approved, change of entity of the buyer (e.g. an individual now wants to purchase the property in the name of a trust), own contribution required and property valuations. Where reconsiderations are requested after the attorney has been instructed, additional costs are incurred and time delays occur. This causes a rework of the same application with the financial institution which also negatively affects the effectiveness of their operational processes.

Table 2: Working hours from submission to an Approval-in-Principal

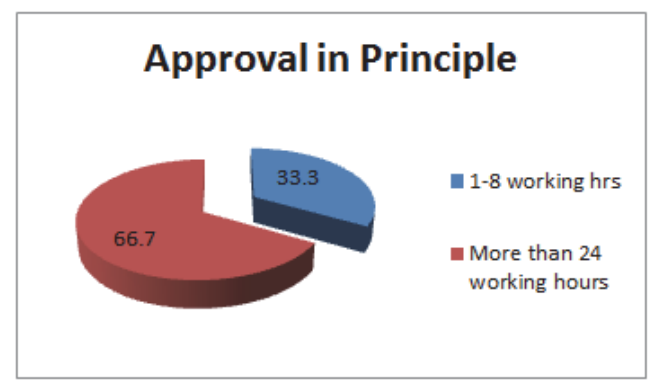

An application for finance can electronically be submitted to the financial institution by using the Comcorp system. An approval in principle is given to indicate that the client has been found to be creditworthy. A valuation of the property still needs to take place before the loan can be finally approved. The survey indicated that more than half of all loans submitted for approval only receive the approval-in-principle after 24 working hours has elapsed.

Table 3: Working hours before Final Approval is granted

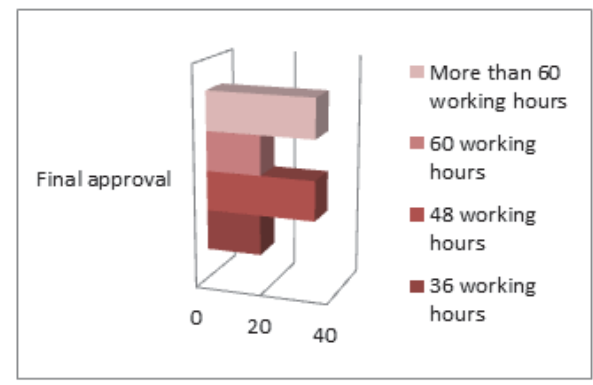

Table 3 illustrates that a final approval may take in excess of 60 hours after the approval-in-principle has been granted. This figure points to huge inefficiencies around the valuation process or the financial institution's ability to complete their processes after valuation has taken place. 
Table 4: Loan applications approved by banks

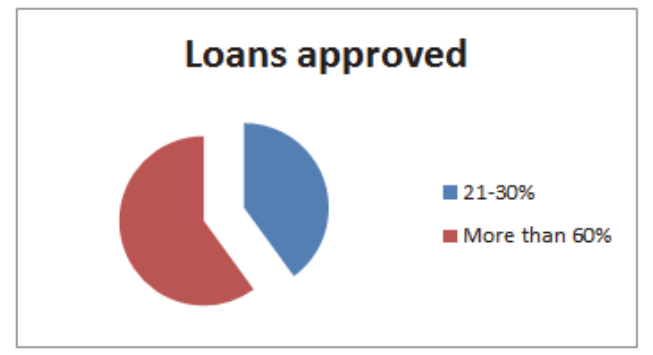

Loan applications approved by banks could range from $100 \%$ loan to value approval, to loans where an own contribution is required. Table 4 shows that while some originators only have up to $30 \%$ of their total applications submitted for loan approval, others receive a higher than $60 \%$ success ratio. The lower approvals would indicate more clients with either a bad credit history or over indebtedness, which indicates that the applicant is unable to afford the loan. It is also noteworthy that the interest rates in SA have been quite low over the last two years. This means that the repayment instalment will increase when interest rates increase.

Table 5: Months until new loans register from time of the Bank's approval

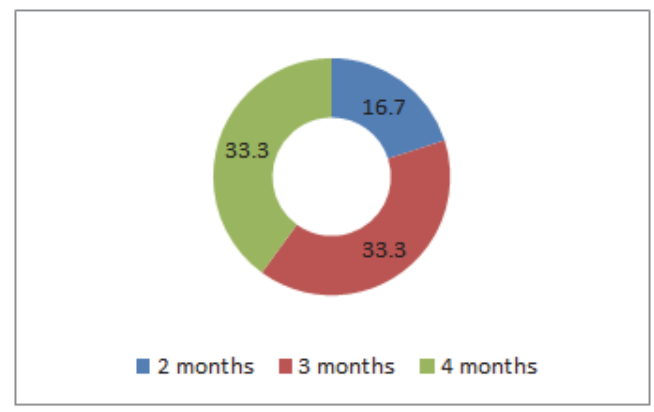

A new loan is a loan for a property that is being purchased by the applicant for the first time. The current registration for the property would be in the previous owner/s name, i.e. the seller/s. $16.7 \%$ of the applicants see their properties registering the title on their names within 2 months, whereas 33.3\% register within 3 months. 33.3\% take 4 months and longer to register.

Table 6: Months until registration of the average further loan from the time the Bank approves the loan

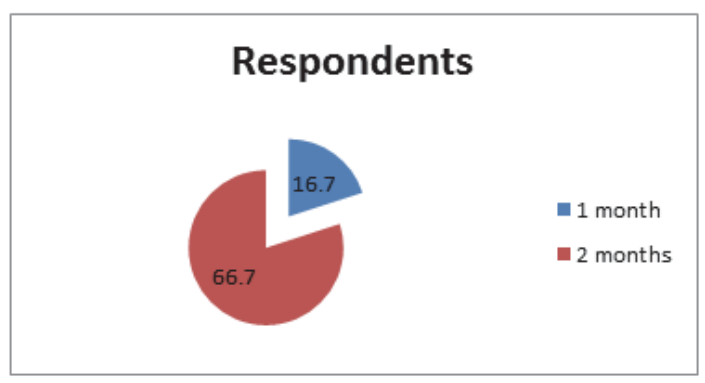

A further loan can be applied for when an existing property owner has acquired new equity in the property, and is applying to access the increased equity of the property by increasing the existing loan. Security for this additional loan is done by means of an additional registration. $16.7 \%$ of the MO's transactions registered within 1 month, whereas $66.7 \%$ of the MO's saw their transactions registering in 2 months. Title does not transfer again in this instance, hence why the further advance seemingly registers quicker than a new loan. 
Table 7: Who informed you of the progress of the home loan application?

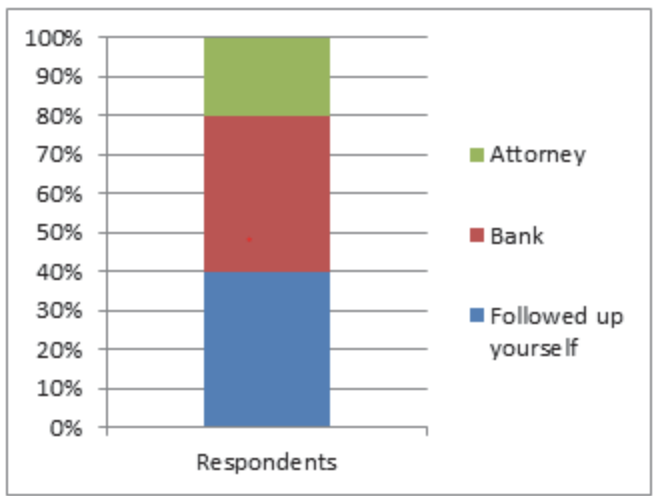

In most instances the $\mathrm{MO}$ is updated of the progress of the home loan application by the bank or they phone around to follow up themselves. Attorneys only inform MO's of the progress $16.7 \%$ of the time. This makes it very difficult for the MO to keep track of the loan. The MO has a vested interest to see the property register as soon as possible as they only receive their commission after the loan has registered.

Table 8: Percentage of 1-10\% own contribution needed by buyers

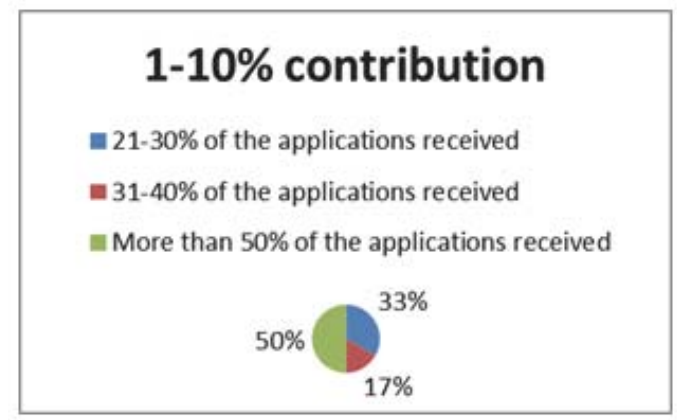

21-30\% of the MO's had applications approved subject to an own contribution by the buyer of 1-10\%. Other MO's encounter situations where 31-40\% of their applications needed a 1-10\% own contribution, while another group of MO's stated that more than $50 \%$ of their applications needed a 1-10\% own contribution. An own contribution softens the bank's risk in the sense that some of the risk of default is passed on to the buyer.

Table 9: 11-20\% Deposit required by a prospective buyer

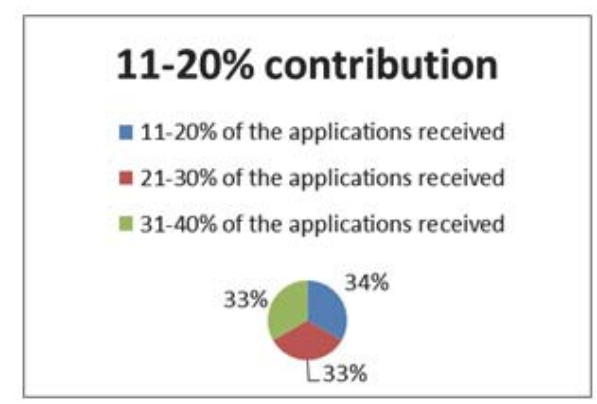

Table 9 indicates that $11-20 \%$ of applications received to be processed by a specific group of originators require a 11 $20 \%$ own contribution, while $21-30 \%$ and $31-40 \%$ of applications from other originators respectively, require a $11-20 \%$ own contribution by buyers. 
Table 10: 21-30\% Deposit required by a prospective buyer

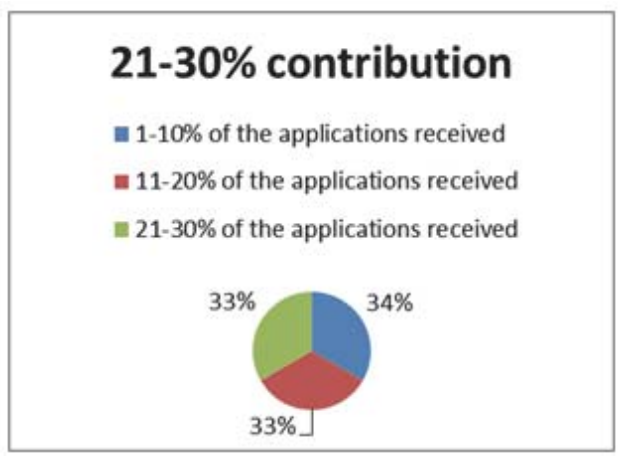

Table 10 indicates that up to $30 \%$ of applications received by originators require a $21-30 \%$ of own contribution from buyers.

It seems as if banks mostly inform originators of the progress status of the application submitted to them for a loan. Furthermore, MO's follow up themselves where necessary as not all attorneys seem to provide this feedback to them regularly enough. Although 100\% loans are still approved in some instances by banks in SA, most home buyers now need to provide an own contribution which can be as high as $30 \%$ or even more. Reconsiderations can also be as high as $40 \%$ in some instances.

\section{Conclusion}

This study examined mortgage originator roles and activities in different countries and in South Africa. The study showed that other countries have embarked on strategies to regulate mortgage origination. As a result legislation may have been amended to incorporate origination, and specific professional bodies have been given a mandate to regulate the origination industry. Accredited training has been adopted and the roles and responsibilities, conduct and fee structures of MO's are regulated by these professional bodies. Mortgage origination in SA has not been regulated yet. Much can be learnt from other countries in this regard.

The questionnaires indicated that banks require an own contribution from buyers of new properties which can be as high as 30\% and more. Where buyers are unable to afford the amount of an own contribution, originators will have a tough task to grow their business, given the fact that they earn commission only from loans that have registered. Reconsiderations are as high as $40 \%$ of some of the business, which can cause further delays with regard to the registration of property.

\section{References}

Ambrose, Brent W. and Conklin, James, Mortgage Brokers, Origination Fees, and Competition (March 26, 2012). Available at SSRN: http://ssrn.com/abstract=2029007 or http://dx.doi.org/10.2139/ssrn.2029007

Berndt, A., Hollifield, B., \& Sandås, P. (2013). How Subprime Borrowers and Mortgage Brokers Shared the Pie. Available at SSRN.

Jones, J. (2010). Mortgage Brokers Explained. Accessed from http://www.iproperty.com.sg/news/2569/Mortgage-Brokers-Explained on 14 March 2014.

Kuling, A.P.F. (2013). Interviews held with mortgage originator in The Netherlands.

Merix. (n.d.). Tips for building your mortgage business. Accessed from http://www.merixfinancial.com/mortgage-broker/build-mortgagebroker-business on 20 March 2014.

Muchanya, G. (2014). The current dynamics and the future of mortgage distribution in South Africa (Doctoral dissertation).

Property24. (2012). Accessed from http://www.property24.com/articles/benefits-of-using-a-bond-originator/15422 on 20 March 2014.

Property News. 2009. Accessed from http://www.privateproperties.co.za/news/market-news/regulation-of-mortgage-originationimminent.htm?id=291 on 20 March 2014.

Orchard, R. 2013. Mortgage Brokers: A Rising Trend in Australia's Mortgage Loan Industry. Accessed on 11 March 2014 on http://www.swanriverfinance.com/mortgage-brokers-a-rising-trend-in-australias-mortgage-loan-industry.

Tomlinson, M. R., \& Burke, T. (2012). Household debt: mortgage lending practices and the housing market. Australia's Unintended Cities: The Impact of Housing on Urban Development, 69. 